\title{
Linear and spatial variability of eucalyptus dendrometric attributes correlated with the properties of a Typic Haplustox soil (Oxisol) in the Brazilian savannah
}

\section{Variabilidade linear e espacial dos atributos dendométricos do eucalipto correlacionados com atributos de um latossolo no cerrado brasileiro}

\author{
Iris Mariane da Silva Martins ${ }^{1}$; Tatiane Carla Silva2; Maria Julia Betiolo Troleis²; \\ Paulino Taveira de Souza2; Karla Nascimento Sena2; Rafael Montanari ${ }^{3 *}$
}

\section{Highlights}

Geostatistics is a tool used for site-specific zone management.

Soil microbiology is important for environmental sustainability.

Eucalyptus is a culture of great economic importance in Brazil.

\begin{abstract}
Effects of soil attributes using the geostatistical tool improves the interpretation of specific soil management. Thus, this study aimed to evaluate the physical, chemical, and microbiological properties of a Typical Haplustox (Oxisol), identifying those with the best linear and spatial correlation with eucalyptus (Eucalyptus spp.) vegetative growth. The experiment was conducted at the Teaching, Research, and Extension Farm (FEPE) of the Universidade Estadual Paulista (UNESP), Campus of Ilha Solteira. Thirty-five points spaced 13 meters apart were demarcated for analysis, which were distributed in 5 rows of 7 points each. From each point, 2 soil samples were collected from the 0-10 cm depth layer. The physical, chemical, and microbiological soil properties evaluated were: sand, silt, and clay contents; penetration resistance (PR), gravimetric moisture $(G M)$, real density $(\mathrm{RD})$, microbial biomass carbon $(\mathrm{MBC})$, respirometry $\left(\mathrm{CO}_{2}-\mathrm{C}\right)$, metabolic quotient $\left(\mathrm{qCO} \mathrm{C}_{2}\right)$, organic matter content $(\mathrm{OM})$, and hydrogenionic potential $(\mathrm{pH})$. The eucalyptus attributes assessed were: plant height $(\mathrm{PH})$ and circumference at breast height $(\mathrm{CBH})$. Each attribute was analyzed by descriptive statistics using the SAS software. Data frequency distribution was verified by the Shapiro Wilk method, and geospatial changes were analyzed by the GS+ software. The soil property that best explained the variability in eucalyptus dendrometric attributes was real density (RD). Except for RD, all properties did not show spatial

1 Student of the Graduate Program in Agronomy, Universidade Estadual Paulista "Júlio de Mesquita Filho", UNESP, Ilha Solteira, SP, Brazil. E-mail: iris.martins@unesp.com

2 Students of the Doctoral Course of the Postgraduate Program in Agronomy, UNESP, Ilha Solteira, SP, Brazil. E-mail: tatiane.carla@unesp.br; julia_troleis@hotmail.com; paulinoagro@gmail.com; karla.sena@unesp.br

${ }^{3}$ Prof. Dr., Postgraduate Program in Agronomy, Department of Plant Health, Rural Engineering, and Soils, DEFERS, UNESP, Ilha Solteira, SP, Brazil. E-mail: r.montanari@unesp.br

* Author for correspondence
\end{abstract}

Received: Apr. 25, 2021 - Approved: Oct. 15, 2021 
dependence (i.e., pure nugget effect), which significantly represents eucalyptus vegetative performance.

Key words: Eucalyptus grandis. Geostatistics. Soil management. Soil microbiology. Site-specific zone management.

\section{Resumo}

Efeitos dos atributos do solo utilizando a ferramenta geoestatística melhora a interpretação do manejo específico do solo. Assim, este estudo teve como objetivo avaliar as propriedades físicas, químicas e microbiológicas de um Latossolo Vermelho Típico, identificando aqueles com melhor correlação linear e espacial com o crescimento vegetativo do eucalipto (Eucalyptus spp). O experimento foi conduzido na Fazenda de Ensino, Pesquisa e Extensão (FEPE) da Universidade Estadual Paulista (UNESP), Campus de Ilha Solteira. Foram demarcados para análise 35 pontos espaçados de 13 metros entre si, os quais foram distribuídos em 5 fileiras de 7 pontos cada. De cada ponto, 2 amostras de solo foram coletadas da camada de 0-10 cm de profundidade. As propriedades físicas, químicas e microbiológicas do solo avaliadas foram: teores de areia, silte e argila; resistência à penetração (PR), umidade gravimétrica (GM), densidade real (RD), carbono da biomassa microbiana (MBC), respirometria $\left(\mathrm{CO}_{2}-\mathrm{C}\right)$, quociente metabólico $(\mathrm{qCO})$, conteúdo de matéria orgânica $(\mathrm{OM})$ e potencial hidrogeniônico $(\mathrm{pH})$. Os atributos do eucalipto avaliados foram: altura da planta (AP) e circunferência à altura do peito (CAP). Cada atributo foi analisado por estatística descritiva usando o software SAS. A distribuição da frequência dos dados foi verificada pelo método Shapiro Wilk, e as mudanças geoespaciais foram analisadas pelo software GS +. A propriedade do solo que melhor explicou a variabilidade nos atributos dendrométricos do eucalipto foi a densidade real (RD). Exceto para RD, todas as propriedades não apresentaram dependência espacial (ou seja, efeito pepita pura), o que representa significativamente o desempenho vegetativo do eucalipto.

Palavras-chave: Eucalyptus grandis. Geostatística. Menojo do solo. Microbiologia do solo. Zonas específicas de manejo.

\section{Introduction}

Eucalyptus is a plant genus native to Australia and is one of the main raw material sources for paper and cellulose production. This genus encompasses more than 600 species, varieties, and hybrids (Schumacher \& Viera, 2016). According to the Brazilian Tree Industry, these plants have great importance for the Brazilian economy, with 5.5 million hectares planted, an average yield of 39 $\mathrm{m}^{3}$ ha-1 year-1. However, several factors may affect crop yields such as planting site, cultural practices, and available inputs (Empresa Brasileira de Pesquisa Agropecuária [EMBRAPA], 2019).
In 2019, the Brazilian area of silviculture totaled 9.98 million hectares, which is $1.2 \%$ higher than in 2018. Brazilian forest plantations are composed of $76.3 \%$ eucalyptus, $19.8 \%$ pine, and only $3.9 \%$ with other forest species, mainly acacias, araucarias, paricás, and teaks. These areas grew by $1.3 \%$ in 2020, but species proportions remained unchanged (Brainer, 2021). Such an increase can be explained by eucalyptus rapid growth, wood use diversification, and adaptability to different edaphoclimatic conditions. However, the eucalyptus plantation yields in Brazil are still quite variable and may reach an average of 60 $\mathrm{m}^{3}$ ha- 1 in a seven-year rotation (Galindo et al., 2018). 
When transformed into arable areas, soil under natural vegetation cover undergoes significant changes in quality, which varies with tillage system and can negatively interfere with ecological processes (Vinhal-Freitas, Corrêa, Wendling, Bobuská \& Ferreira, 2017). Thus, soil physical and chemical traits are changed when under eucalyptus production if compared to its natural condition, which may cause its degradation. Therefore, to ensure production sustainability, these changes should be quantified through monitoring and field measurements of these soil properties (Ferreira et al., 2018).

Currently, aiming at sustainability, soil physical and chemical properties, as well as plant attributes, have been often quantified and transformed into soil quality indicators (Coutinho et al., 2017). These indexes can be measurable factors (soil properties), soil processes (nutrient mineralization), or even cover numerous soil measurements, such as density, porosity, organic matter content, among others (Freitas et al., 2017).

Brazilian savannah soils are adverse to crop growth. In this sense, precision silviculture using geostatistics as a tool to assess spatial dependence of georeferenced data and fit them into semivariograms according to the distances between observations. From this semivariogram, kriging maps can be generated for each soil or plant property to represent their spatial variability, and later obtain specific zones for soil and crop management (Santos, Silva, Leite \& Cruz, 2017).

Given the above, this study aimed to correlate the physical, chemical, and microbiological properties of a Typical
Haplustox (Oxisol) with eucalyptus dendrometric attributes linearly and spatially, and define the one that best explains eucalyptus growth variability.

\section{Material and Methods}

The experiment was carried out at the Teaching, Research, and Extension Farm (FEPE) of the Universidade Estadual Paulista (UNESP), Campus of Ilha Solteira, in the municipality of Selvíria, Mato Grosso do Sul State, Brazil $\left(20^{\circ}\right.$ $20^{\prime} \mathrm{S}$ latitude, $51^{\circ} 23^{\prime} \mathrm{W}$ longitude, and 335$\mathrm{m}$ altitude). Eucalyptus (Eucalyptus grandis) plants were planted in this area between February 8 and 10, 2010, and sampling was carried out on April 12, 2019. Thirty-five points spaced 13 meters apart were demarcated for analysis, which were distributed in 5 rows of 7 points each, with random distances. From each point, 2 soil samples were collected from the $0-10 \mathrm{~cm}$ depth layer using a hoe, sieved through a $2.0-\mathrm{mm}$ mesh screen, stored in plastic bags, and transported to the laboratory.

The local soil was classified as a Latossolo (Oxisol) with clayey texture (Demattê, 1980 updated according to Santos, Silva, Leite \& Cruz (2018).

Annual rainfall varies from 1,200 to $1,500 \mathrm{~mm}$, and annual average temperature is $22.7^{\circ} \mathrm{C}$. The local climate is classified as type Aw according to the Köppen's classification, which stands for a humid tropical climate, with rainy summers and dry winters (Alvares et al., 2013). Rainfall data between 03/15/19 and 04/15/19 were $64.20 \mathrm{~mm}$ in total (Figure 1). 


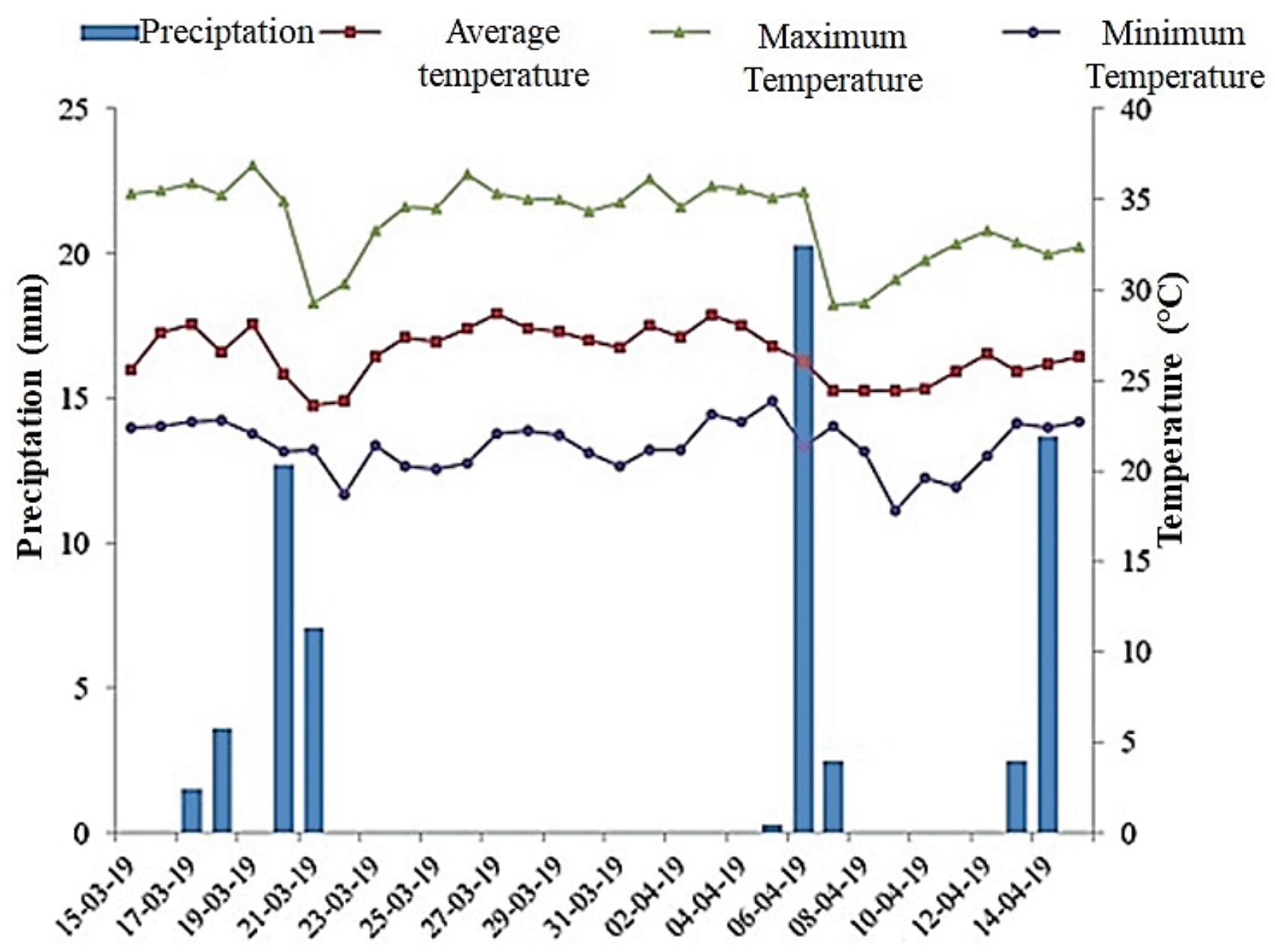

Figure 1. Rainfall at the time of data collection.

Source: UNESP Irrigation Laboratory - Ilha Solteira.

The soil properties evaluated were texture (sand, silt, and clay contents), penetration resistance (PR), gravimetric moisture (GM), real density (PD), microbial biomass carbon $(\mathrm{MBC})$, respirometry $\left(\mathrm{CO}_{2}-\mathrm{C}\right)$, metabolic quotient $\left(\mathrm{qCO}_{2}\right)$, organic matter content (OM), and hydrogenionic potential $(\mathrm{pH})$. Sand, silt, and clay contents were determined by the pipette method (Teixeira, Donagemma, Fontana \& Teixeira, 2017). Penetration resistance (PR) was evaluated at the 0.00-0.10 $\mathrm{m}$ depth layer using an impact penetrometer and calculated as in Equation 1:

$$
\begin{gathered}
P R=\{\{5.581+6.891 *\{[N / P-A] * 10\}\} \\
* 0.0981\}(1)
\end{gathered}
$$

Wherein:

$\mathrm{PR}=$ soil penetration resistance $(\mathrm{MPa})$;

$\mathrm{N}=$ number of impacts of the penetrometer hammer for a reading;

$A$ and $P=$ readings before and after impacts (cm), respectively (Stolf et al., 2014). 
Gravimetric moisture (GM) was determined as in Equation 2:

$$
\mathrm{GM}=(\mathrm{WW}-\mathrm{DW}) / \mathrm{DW}(2)
$$

Wherein:

$\mathrm{GM}=$ soil gravimetric moisture $\left(\mathrm{kg} \mathrm{kg}^{-1}\right)$;

WW = soil sample wet weight;

DW = soil sample dry weight (Teixeira et al., 2017).

Soil real density (RD) was also determined using Equation 3:

$$
\mathrm{RD}=\operatorname{MDS} /(50-V)(3)
$$

Wherein:

$\mathrm{RD}=$ real density $\left(\mathrm{kg} \mathrm{dm}^{-3}\right) ;$

MDS = mass of dry soil at $105^{\circ} \mathrm{C}(\mathrm{kg})$;

$\mathrm{V}=$ volume of alcohol spent $\left(\mathrm{m}^{-3}\right)$ (Teixeira et al., 2017).

Carbon content in the soil microbial biomass was determined according to EMBRAPA's method (Silva, Silva \& Mercante, 2012), wherein carbon concentration was estimated as follows: $C$ ( $\left.\mathrm{mg} \mathrm{L}^{-1}\right)=(($ Absorb. - a) / b) * (V / P) * F. Afterwards, the following equation was applied, using a correction factor (Kc) of 0.33: $\mathrm{MBC}=$ (C (fumigated samples) $-\mathrm{C}$ (non-fumigated samples)) / 0.33.

Respirometry $\left(\mathrm{CO}_{2}-\mathrm{C}\right)$ was conducted together with $\mathrm{MBC}$ analysis and determined as the amount of $\mathrm{CO}_{2}$ released from nonfumigated soil during seven days of incubation. The data were expressed as $\mathrm{mg}$ $\mathrm{CO}_{2}-\mathrm{C}$ per $\mathrm{kg}$ soil. $\mathrm{QCO}_{2}$ was estimated as the ratio between $\mathrm{CO}_{2}-\mathrm{C}$ released and $\mathrm{MBC}$
(Anderson \& Domsch, 1993) and expressed as (mg CO${ }_{2}-\mathrm{C}$ mg C-MB-1 $\mathrm{kg}^{-1} \mathrm{~h}^{-1}$ ) $.10^{3}$, based on the expressions in (4) and (5):

$$
\begin{gathered}
\mathrm{qCO}_{2}=\mathrm{MR} / \mathrm{MBC}(4) \\
\mathrm{CO}_{2}-\mathrm{C} \text { released }=\mathrm{MRT} / \mathrm{h}(5)
\end{gathered}
$$

Wherein:

$\mathrm{qCO}_{2}=$ metabolic quotient ( $\mathrm{mg} \mathrm{CO}$-C.mg C-MB $\left.{ }^{-1} \mathrm{~kg}^{-1} \mathrm{~h}^{-1}\right) \cdot 10^{3}$;

MRT = microbial respiration rate $\left(\mathrm{mg} \mathrm{CO}_{2}-\mathrm{C} . \mathrm{kg}\right.$ of soil-1 ${ }^{-1}$;

$\mathrm{CO}_{2}-\mathrm{C}$ released $=$ microbial activity $\left(\mathrm{mg} \mathrm{CO}_{2}-\mathrm{C}\right.$. $\mathrm{kg}$ of soil $\left.^{-1} \mathrm{~h}^{-1}\right)$;

$\mathrm{h}=$ incubation hours for microbial respiration analysis;

$\mathrm{MBC}=$ microbial biomass carbon (mg C-MB $\mathrm{kg}^{-1}$ of dry soil).

Soil organic matter contents (OM) and hydrogen potential in calcium chloride $(\mathrm{pH})$ were analyzed.

The eucalyptus dendrometric attributes evaluated were plant height $(\mathrm{PH})$ and circumference at breast height $(\mathrm{CBH})$. They were measured in 35 trees located at the same place where soil samples were collected. While $\mathrm{PH}$ was measured by a Haglof electronic clinometer $10 \mathrm{~m}$ away from the tree, $\mathrm{CBH}$ was measured with the aid of a measuring tape at $1.30 \mathrm{~m}$ above the soil surface.

Each attribute/ property was analyzed by descriptive statistics (mean, median, minimum, maximum, standard deviation, coefficients of variation, kurtosis, skewness, and probability test) using the SAS software (Schlotzhaver \& Little, 1997). After, data 
frequency distribution was analyzed by Shapiro and Wilk method (Shapiro \& Wilk, 1965) at $1 \%$ error probability. The ShapiroWilk W statistic tests the null hypothesis that data was sampled from a normal distribution population.

Geospatial fit was developed with the aid of the GS+ 7.0 software (Robertson, 1998). Simple semivariograms were created and fitted to all the studied plant attributes and soil properties (Vieira, 2000). The model that represented the fit of semivariograms was defined by cross validation, as well as the size of the neighborhood that provided the best kriging mesh. Nugget effect (CO), range (AO), sill $(\mathrm{CO}+\mathrm{C})$, and spatial dependence evaluator (SDE) were defined for each attribute/ property studied. Spatial dependence (SDE) was classified by the method of Cambardella et al. (1994), adapted by GS+ 2008 (Robertson, 2008), according to Equation 6 :

$$
\mathrm{ADE}=[\mathrm{C} /(\mathrm{C}+\mathrm{CO})] * 100(6)
$$

Wherein:

SDE = spatial dependency evaluator;

$\mathrm{C}=$ structural variance;

$\mathrm{C}+\mathrm{CO}=$ sill.

\section{Results and Discussion}

\section{Data descriptive analysis}

Table 1 shows the descriptive analysis of the studied soil properties and eucalyptus attributes. According to Pimentel-Gomes and Garcia (2002), the variability of an attribute can be classified given the magnitude of its coefficient of variation (CV), with the classes being determined as: low ( $\mathrm{CV} \leq 10 \%$ ), medium $(10 \%<\mathrm{CV} \leq 20 \%)$, high (20\% <CV $\leq 30 \%)$, and very high (CV> 30\%). In this sense, both plant height $(\mathrm{PH})$ and circumference at breast height (CBH) showed a medium variability, with CVs of $13.02 \%$ and $14.52 \%$, respectively. These results corroborate the findings of C. G. R. Lima et al. (2010), who studied the spatial analysis of eucalyptus dendrometric attributes and found $\mathrm{CV}$ s of 12 and $11.8 \%$ for $\mathrm{PH}$ and $\mathrm{CBH}$, respectively. 


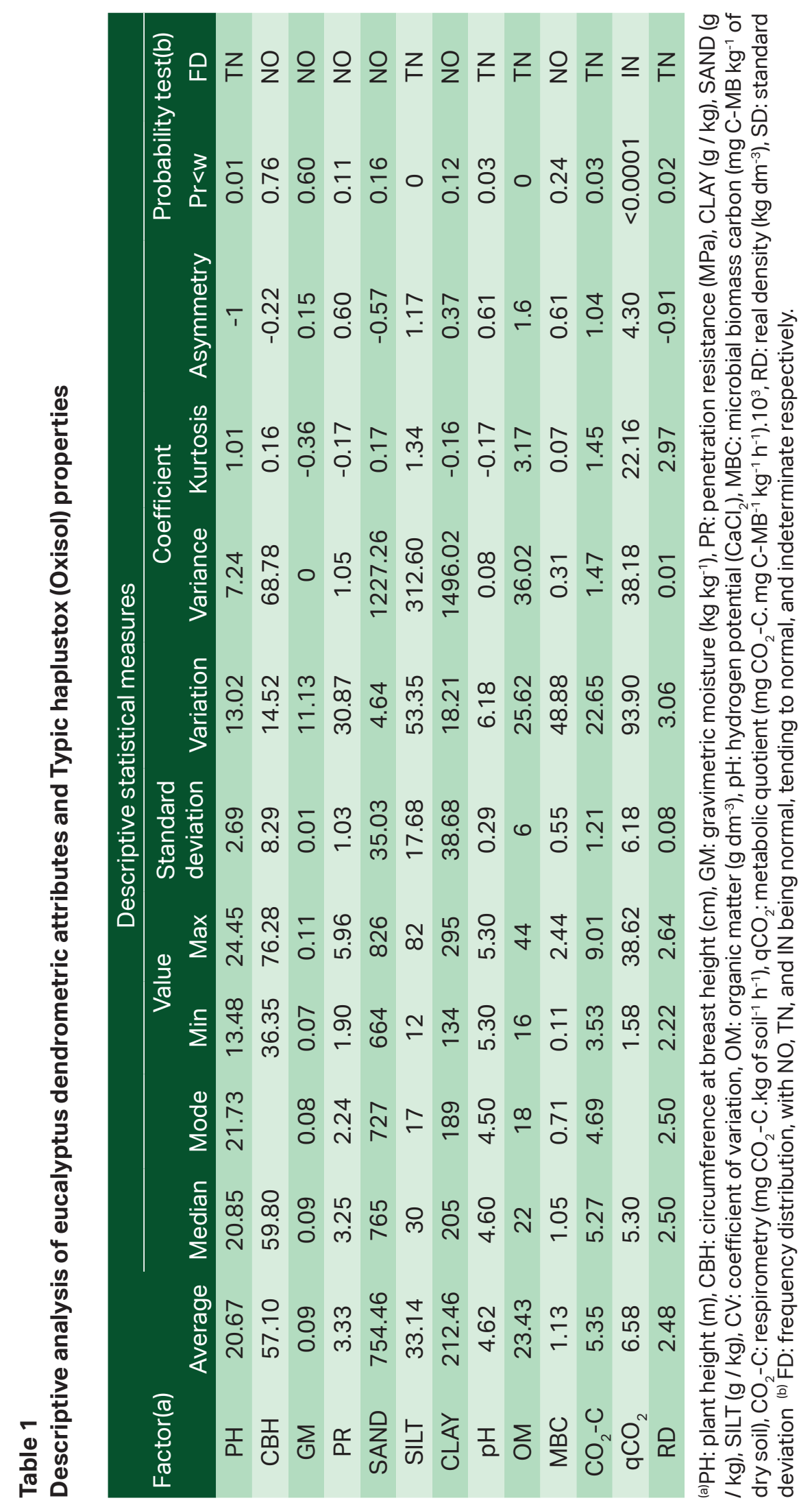




\section{Soil properties}

Silt, clay, and sand content variabilities were classified as very high, medium, and low, respectively (53.35, 18.21, and 4.64\% CV). These findings agree with those of Klinke, Oliveira and Pereira, (2017), who studied the physical properties of a Typic Haplustox (Oxisol) and obtained a very high variability for silt, medium for clay, and low for sand, with CVs of $52.03 \% ; 17.37 \% ; 6.18 \%$, respectively. Thus, the granulometric attributes of the soil showed different variability, silt with very high variability, clay with medium variability, and sand with low variability, which indicates soil heterogeneity.

The variability in mechanical penetration resistance (PR) was classified as very high $(\mathrm{CV}=30.87 \%)$. This result goes against the finding of C. G. R. Lima et al. (2010), who observed a medium variability for soil PR. This very high variability is due to the low soil humidity at sampling time and absence of soil tillage for a long period, as eucalyptus plantations had been established nine years ago.

The soil properties organic matter (OM) and $\mathrm{pH}$ had CVs of 25.62 and $6.18 \%$, respectively, thus being classified as high for $\mathrm{OM}$ and low for $\mathrm{pH}$. Our results for $\mathrm{OM}$ content were different from those of $E$. S. Lima et al. (2017), who studied an Entisol (Quartzipsamment) and reported a low variability $(7.81 \%)$; however, their results for $\mathrm{pH}(3.73 \%)$ were consistent with ours, also showing a low variability.

Respirometry (CO2-C) also showed a high variability (CV $=22.65 \%)$. This occurred because this property is influenced by $\mathrm{OM}$ contents. Likewise, microbial biomass carbon
(MBC) and metabolic quotient (qCO2) showed a very high variability in the studied soil depth layer $(0-10 \mathrm{~cm})$, with $\mathrm{CVs}$ of $48.88 \%$ and 93.90\%, respectively. However, gravimetric moisture (GM) showed a medium variability, with a CV of $11.13 \%$.

Finally, the variability in real density (RD) was low (CV= 3.06\%). This is justified by the influence of $\mathrm{RD}$ on this variable, with the mineral of origin present in the soil being kaolinite, which does not vary with sampling spacing.

Frequency distribution of soil properties and plant dendrometric attributes

When any statistical variable has a normal frequency distribution, the most suitable measure of central tendency to represent it is the mean. Conversely, if it has a lognormal distribution, it can be represented by the median or mean (Dalchiavon, Montanari \& Andreotti, 2017). Shanmugam and Chattamvelli (2016) highlighted the relevance of skewness and kurtosis in such study, stating that skewness quantifies the distribution bias regarding the mean, while kurtosis measures the peak (or flatness) of a distribution. Still, skewness coefficient is more sensitive to extreme values than are the mean and standard deviation, as a single value can greatly influence such coefficient (Demartino \& Ricciardelli, 2017).

Table 1 demonstrates that $\mathrm{CBH}$; $\mathrm{GM}$; PR; sand and clay contents; and MBC showed a normal frequency distribution, with positive skewness coefficients for GM, PR, clay content, and $\operatorname{MBC}(0.15,0.60,0.37$, and 0.61$)$ but negative ones for $\mathrm{CBH}$ and sand content 
(-0.22 and -0.57). Kurtosis coefficients, in contrast, were positive for $\mathrm{CBH}(0.16)$, sand content (0.17), and MBC (0.07). However, these soil properties were not significant at $5 \%$ probability by the normality test of Shapiro and Wilk (1965), with probabilities of $0.76,0.16$, and 0.24 , respectively, representing a normal frequency distribution.

The plant attribute $\mathrm{PH}$, as well as the soil properties silt, $\mathrm{pH}, \mathrm{OM}$, and $\mathrm{CO} 2-\mathrm{C}$, had skewness coefficients of $-1.00,1.17,0.61$, 1.60, and 1.04, with frequency distributions tending to normal, but skewness coefficients considered low and little accentuated for most of the soil chemical properties. These results indicate distributions close to the symmetric one, except for qCO2, which had an indeterminate distribution, with higher skewness (4.30) and kurtosis (22.16) coefficients. Negative skewness coefficients show that the values tend to concentrate above the average; therefore, the more expressive this trend, the greater the value obtained. On the other side, for positive coefficients, the situation is reversed (Neves, Santos, Santos, Melo \& Santos, 2013).

\section{Average of the studied variables:}

\section{Plant dendrometric attributes}

$\mathrm{PH}$ had an average value of 20.67 meters (Table 1). This indicates excellent performance when compared to the results of Tanvir, Siddiqui and Shah (2002), who studied a $E$. camaldulensis progeny and obtained an average $\mathrm{PH}$ of 14.63 meters for 10 -year-old plants.

$\mathrm{CBH}$ showed an average value of 0.571 meters. This denotes an excellent and satisfactory productivity performance, especially when compared to the study of Tanvir et al. (2002), wherein averages between 0.119 and 0.158 meters were reported for 10 -year-old plants from 13 provenances. These authors also added that these results are influenced by water availability and temperature.

\section{Soil properties}

Mean PR was 3.33 MPa (Table 1), that is, high according to the general classification. However, mainly for eucalyptus plantations, this high value does not interfere so negatively with productivity. Among other factors, soil physical quality for plant growth is influenced by soil resistance to mechanical penetration of roots. This attribute deserves attention since it directly affects plant development (Stefanoski, Santos, Marchão, Petter \& Pacheco, 2013). As $P R$ varies with soil moisture, the high $P R$ can be explained by the low mean GM (0.09 $\left.\mathrm{kg} \mathrm{kg}^{-1}\right)$.

Mean $\mathrm{qCO}_{2}$ was 6.58 (mg $\mathrm{CO}_{2}-\mathrm{C} . \mathrm{Mg}$ C-MB-1 $\left.\mathrm{kg}^{-1} \mathrm{~h}^{-1}\right) \cdot 10^{3}$. T. E. B. Santos et al. (2018) obtained a value close to ours [5.44 $\mathrm{mg} \mathrm{CO}_{2}-\mathrm{C}$. mg C-MB $\left.{ }^{-1} \mathrm{~kg}^{-1} \mathrm{~h}^{-1}\right) \cdot 10^{3}$ ], which is considered low. According to Novak et al. (2018), the lower the $\mathrm{qCO}_{2}$, the more efficient the use of $\mathrm{C}$ by microbial biomass, and the lower the $C$ losses in the form of $\mathrm{CO}_{2}$. Hence, higher $\mathrm{qCO}_{2}$ values indicate a greater consumption of readily mineralizable $\mathrm{C}$, increasing $\mathrm{CO}_{2}$ losses, which is undesirable (Pizzani, Schaefer, Deloss, Pelizzon, \& Aleluia, 2018). Means of MBC and $\mathrm{CO}_{2}-\mathrm{C}$ were 1.13 (mg C-MB kg dry soil ${ }^{-1}$ ) and 5.35 ( $\mathrm{mg} \mathrm{CO}_{2}-\mathrm{C} \mathrm{kg} \mathrm{soil}{ }^{-1} \mathrm{~h}^{-1}$ ), respectively. Our result for $\mathrm{CO}_{2}-\mathrm{C}$ disagree with those of T. E. B. Santos et al. (2018), who found a lower value in an agroforestry system (1.52 $\mathrm{mg} \mathrm{CO}$-C.kg of 
soil-1 $\left.\mathrm{h}^{-1}\right)$. This low MBC result may have been influenced by the very low soil OM content ( 23.43 $\left.\mathrm{g} \mathrm{dm}^{-3}\right)$.

Mean $\mathrm{pH}$ in $\mathrm{CaCl}_{2}$ was low (4.62). This outcome corroborates that of Montanari (2009), who obtained $\mathrm{pH}$ averages between 4.7 - $4.8\left(\mathrm{CaCl}_{2}\right)$ when studying yield of common beans grown on a dystrophic Typic Haplustox (Oxisol).

Finally, mean soi RD was 2.48 (kg $\mathrm{dm}^{-3}$ ), which is within the ideal according to Kiehl (1979).

Simple linear correlation matrix between soil properties and plant dendrometric attributes

Analysis of correlation and statistical significance between soil properties and plant dendrometric attributes

Correlations between soil properties and plant dendrometric attributes (Table 2) were significant for the following pairs: $\mathrm{PH}$ $x \operatorname{PR}\left(r^{2}=-0.369 *\right), \mathrm{PH} \times \mathrm{MBC}\left(r^{2}=-0.355 *\right)$, $\mathrm{CBH} \times \mathrm{GM}\left(r^{2}=-0.474 * *\right), \mathrm{CBH} \times$ Clay content $\left(r^{2}=-0.345 *\right)$.

Correlations among soil properties (Table 2) were significant for the following pairs: GM and Sand content $\left(r^{2}=-0.350 *\right), G M$ $x$ Clay content $\left(r^{2}=0.416{ }^{*}\right)$, Sand content $x$ Clay content $\left(r^{2}=-0.889^{* *}\right)$, Sand content $x \mathrm{pH}$ $\left(r^{2}=0.501^{* *}\right)$, Sand content $\times$ OM $\left(r^{2}=0.380\right.$ $\left.{ }^{*}\right)$, Sand content $x$ MBC $\left(r^{2}=-0,365 *\right)$, Sand content $\times \mathrm{CO}_{2}-\mathrm{C}\left(r^{2}=0.477^{* *}\right)$, Silt content $\mathrm{x}$ Clay content $\left(r^{2}=-0.419 *\right)$, Silt content $x$ OM $\left(r^{2}=-0.366 *\right)$, Clay content $x \mathrm{pH}\left(r^{2}=-0.434 * *\right)$, Clay content $x \mathrm{MBC}\left(r^{2}=0.434^{* *}\right)$, Clay content and $\mathrm{qCO}_{2}\left(r^{2}=-0.357^{*}\right), \mathrm{pH} \times \mathrm{OM}$ content $\left(r^{2}=\right.$ $\left.0.701^{* *}\right), \mathrm{pH} \times \mathrm{CO}_{2}-\mathrm{C}\left(\mathrm{r}^{2}=0.538^{* *}\right), \mathrm{pH} \times \mathrm{qCO}_{2}$ $\left(r^{2}=0.399 *\right), \mathrm{OM} \times \mathrm{CO}_{2}-\mathrm{C}\left(r^{2}=0.714^{* *}\right)$, and $\mathrm{MBC} \times \mathrm{qCO}_{2}\left(r^{2}=-0.636\right.$ **) .

Attributes can be interpreted by correlation matrix (Table 2) according to their positive (directly proportional) and negative (inversely proportional) correlations, as well as significance at $1 \%\left(^{* *}\right)$ and $5 \%\left(^{*}\right)$.

The inversely proportional correlation between $\mathrm{PH}$ and PR $\left(\mathrm{r}^{2}=-0.369 *\right)$ indicates that the lower the $\mathrm{PR}$, the higher the $\mathrm{PH}$. Therefore, soil should be properly managed to balance $\mathrm{pH}$, improving nutrient availability, and reducing soil compaction. Besides intrinsic soil factors (texture, structure, and mineralogy), PR highly depend on soil moisture (Silva, Olszevski, Pereira \& Silva, 2020), while soil physical factors directly related to plant growth are water retention, aeration, and mechanical resistance to root penetration (Moraes et al., 2020). 


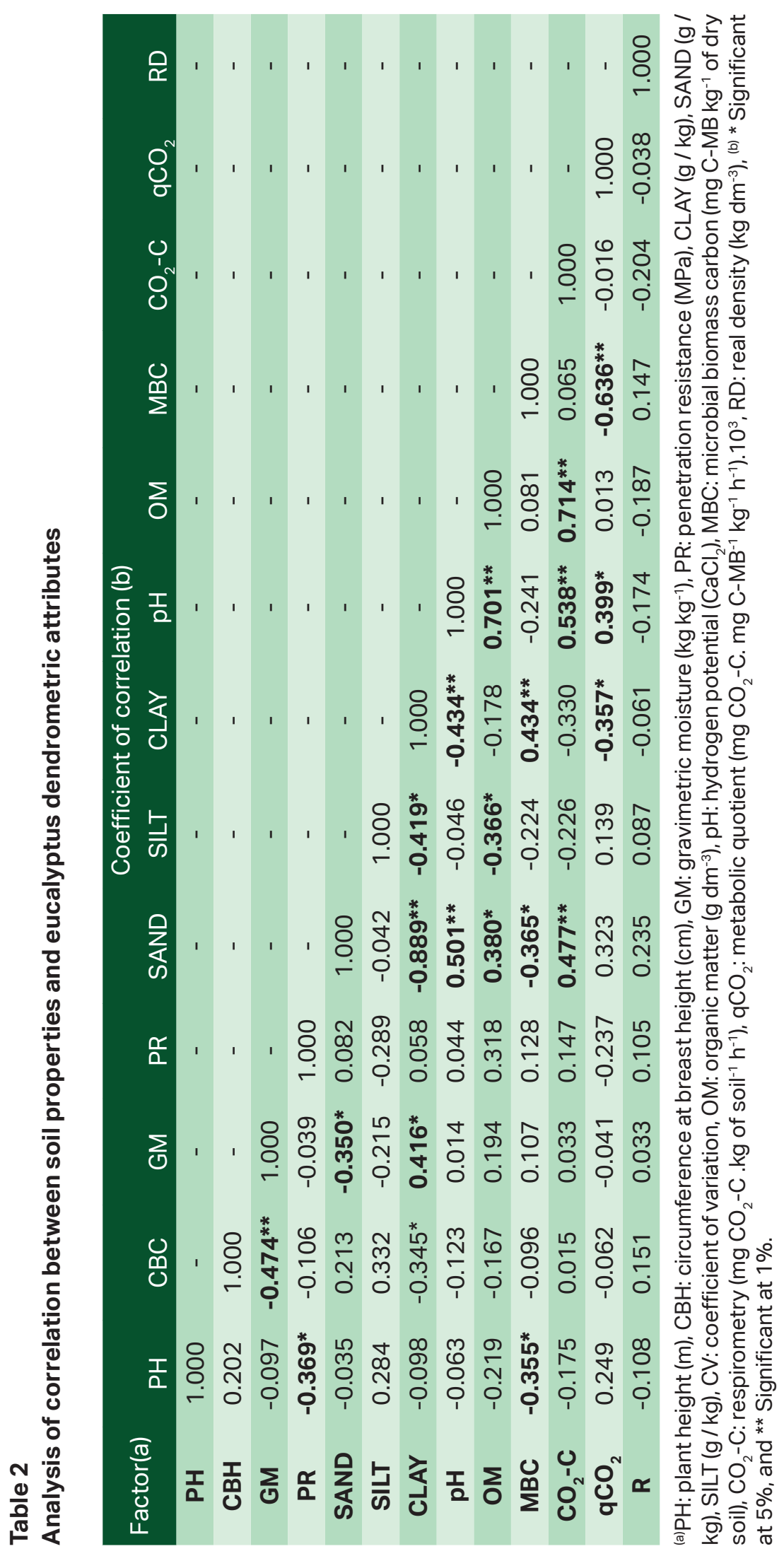


The inversely proportional correlation between $\mathrm{PH}$ and $\mathrm{MBC}\left(\mathrm{r} 2=-0.355^{*}\right.$ ) can be justified by the relevance of climatic conditions and soil microbial biomass to plant growth. Our study was carried out during a dry season (about $64 \mathrm{~mm}$ one month before data collection). Therefore, the soil low humidity impaired microbial biomass formation and maintenance. For Wardle (1992), if considered together, soil chemical properties and macroclimatic variables can often explain global changes in $\mathrm{C}$ and $\mathrm{N}$ activities and levels in microbial biomass, especially in forest soils. Lavelle et al. (1993) stated that rainfall controls decomposition of soil organic matter on a regional scale. Later, Wardle (1998) confirmed that rainfall distribution and soil moisture are the main factors in microbial biomass regulation.

The dendrometric attribute $\mathrm{CBH}$ had an inversely proportional correlation with GM $\left(r 2=-0.474^{* *}\right)$ and Clay content $\left(r 2=-0.345^{*}\right)$, thus confirming the effect of low soil moisture during sampling. Low GM affects soil water content, increasing its mechanical resistance to penetration, impairing plant growth, which is seen in the low CBH. S. M. A. Silva et al. (2021) stated that soil moisture and texture strongly influence its mechanical resistance to root penetration.

Apart from RD, the semivariograms of all soil properties (Figure 2) showed pure nugget effect. This effect indicates unexplained variability that may be due to measurement errors or undetected microvariations, considering distances between samples (Cambardella et al., 1994). The occurrence of pure nugget effect shows that the attributes are spatially independent, have a random distribution, or have a sampling grid spacing greater than necessary to reveal any spatial dependence (Machado, Lana, Lana, Guimarães \& Ferreira, 2007).

The only soil property to show spatial dependence was RD. This was because of the density of the most abundant mineral in the soil, i.e., kaolinite. The parameters of the RD semivariogram were: ALD (active lag distance) $=41.79 \mathrm{~m}$, UR (uniform range) $=6.00 \mathrm{~m}$, Model $=$ Exponential, $\mathrm{CO}$ (nugget effect) $=1 \times 10^{-5}$, $\mathrm{CO}+\mathrm{C}\left(\right.$ sill) $=5.520 \times 10^{-3}, \mathrm{AO}$ (range) $=18.3 \mathrm{~m}$, SSR (sum of squared residuals) $=3.796 \times 10^{-7}$, $\mathrm{R}^{2}$ (coefficient of determination) $=0.827$, and SDE (spatial dependence assessor) $=99.8 \%$.

A cross-validation was generated (Figure $3 b$ ) to validate the semivariogram (Figure 3a). This showed a reasonable distance between continuous (field observation) and dotted (semivariogram estimate) lines; the closer these lines are, the better the semivariogram. Increase in OM was the only factor influencing RD. Thus, to improve soil quality, organic matter must be applied to the areas listed in the kriging map (Figure 4), which have RD above 2.39. 


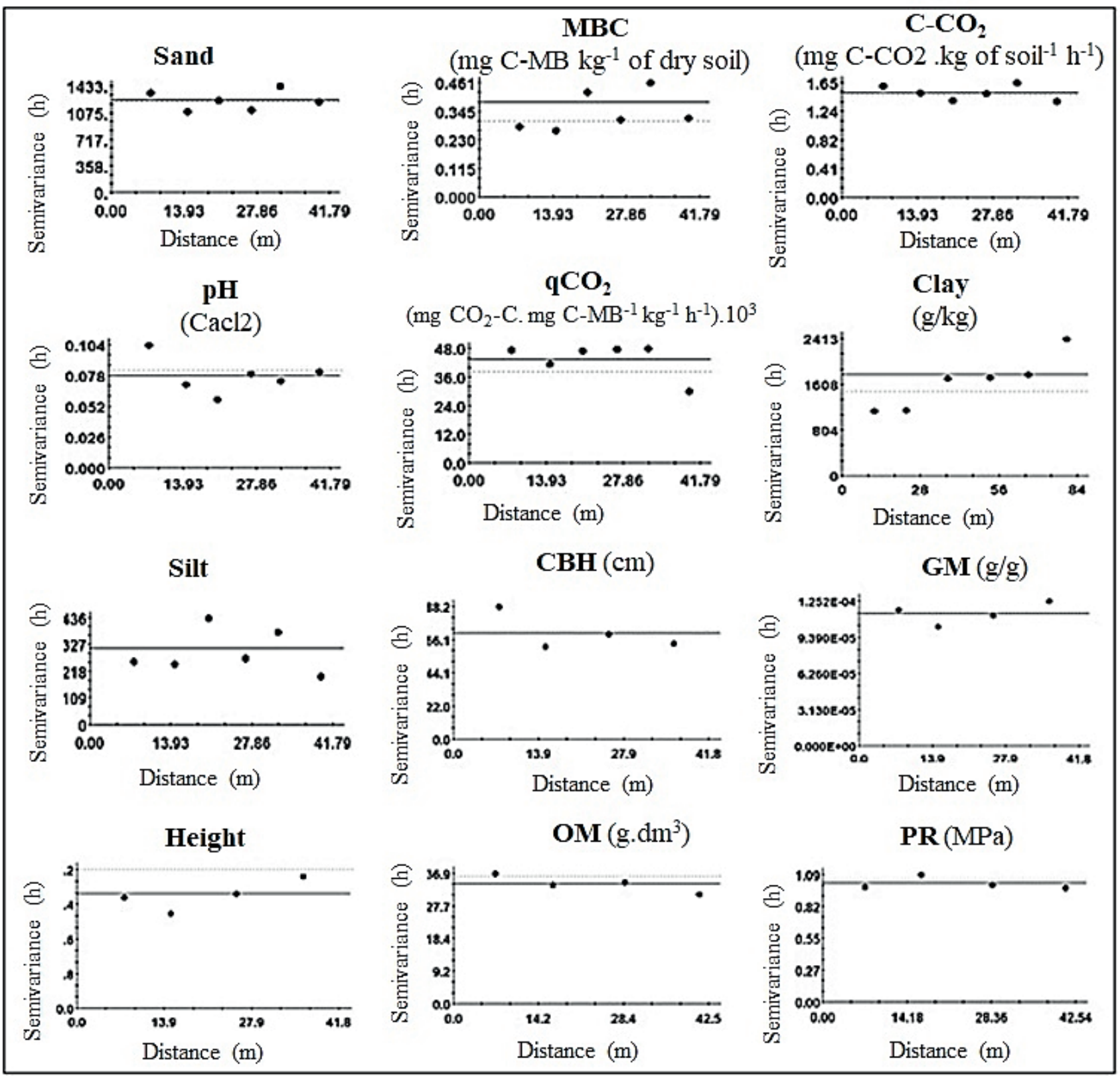

Figure 2. Simple semivariograms of soil properties and eucalyptus dendrometric attributes. 
(a)

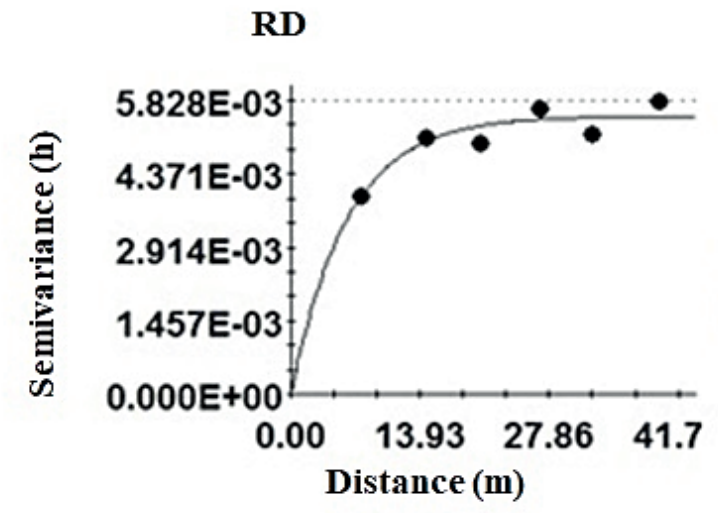

(b)

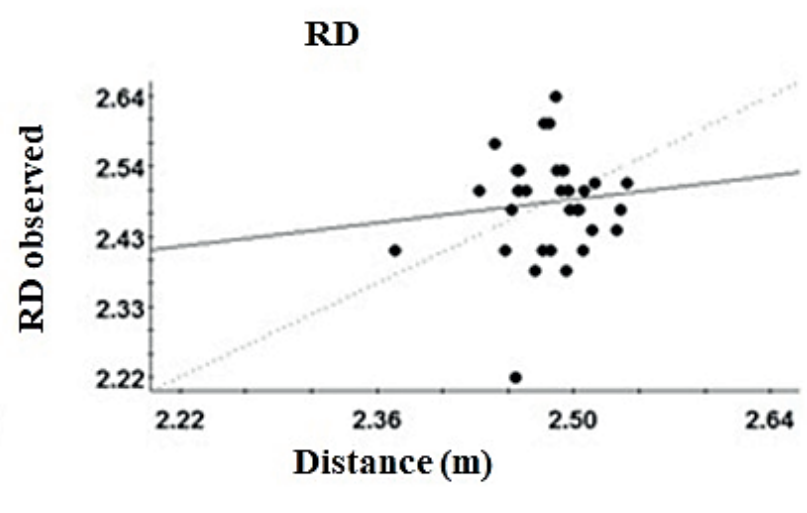

Figure 3. (a) Simple RD semivariogram and (b) Cross-validation of RD ( $\left.\mathrm{kg} \mathrm{dm}^{-3}\right)$.

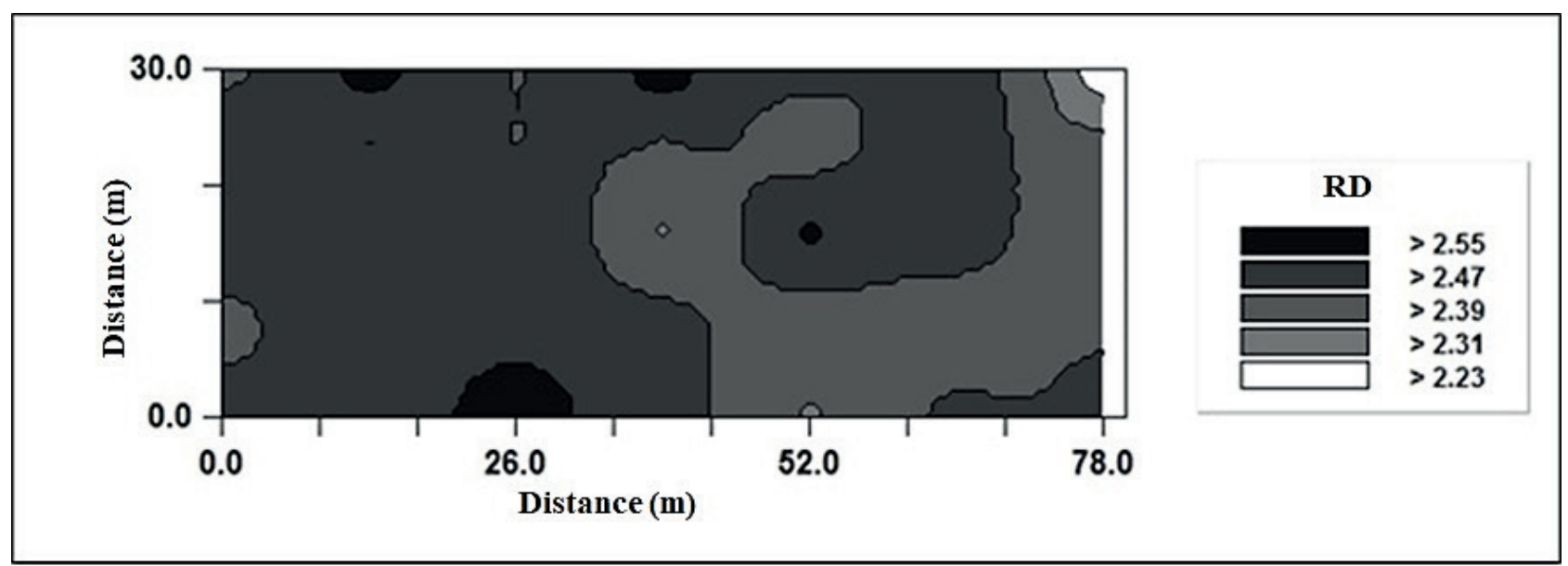

Figure 4. Kriging map for the real density $\left(R D, \mathrm{~kg} \mathrm{dm}^{-3}\right)$.

\section{Conclusion}

Except for real density, the other soil properties showed a pure nugget effect.

Real density was the soil property that best explained the variability in eucalyptus dendrometric attributes, as it was the only to show spatial dependence.

\section{References}

Alvares, C. A., Stape, J. L., Sentelhas, P. C., Gonçalves, J. L., Moraes, G., \& Sparovek. G. (2013). Köppen's climate classification map for Brazil. Meteorologische Zeitschrift, 22(6), 711-728. doi: 10.1127/0941-29 $48 / 2013 / 0507$

Anderson, J. P. E., \& Domsch, K. H. (1993). The metabolic quotient of $\mathrm{CO}_{2}\left(\mathrm{q} \mathrm{CO}_{2}\right.$ ) as a specific activity paramenter to assess the 
effects of environmental condition, such as $\mathrm{pH}$, on the microbial of forest soil. Soil Biology and Biochemistry, 25(3), 393-395. doi: 10.1016/0038-0717(93)90140-7

Brainer, M. S. C. P. (2021). Silvicultura. Caderno Setorial ETENE, 6(64), 1-11.

Cambardella, C. A., Moorman, T. B., Novak, J. M., Parkin, T. B., Karlen, D. L., Turco, R. F., \& Konopka, A. E. (1994). Field-scale variability of soil properties in central lowa soils. Soil Science Society of America Journal, 58(5), 1501-1511. doi: 10.2136/ sssaj1994.03615995005800050033x

Coutinho, F. S., Pereira, M. G., Menezes, C. E. G., Guareschi, R. F., \& Assunção, S. A. (2017). Attributes of soil under agriculture, grazing and three succession stages of forest. Floresta e Ambiente, 24(10), 1-11. doi: 10.1590/2179-8087.091914

Dalchiavon, F. C., Montanari, R., \& Andreotti, M. (2017). Production and quality of Urochloa decumbens (stapf) r.d. webster forage co-related to the physical and chemical properties of the soil. Revista Ceres 64(3), 315-326. doi: 10.1590/0034$737 \times 201764030013$

Demartino, C., \& Ricciardelli, F. (2017). Aerodynamics of nominally circular cylinders: a review of experimental results for Civil Engineering applications. Engineering Structures, 137(1), 76-114. doi: 10. 1016/j.engstruct.2017.01.023

Demattê, J. L. I. (1980). Levantamento detalhado dos solos do "Campus experimental de Ilha Solteira". Piracicaba: Escola Superior de Agricultura "Luiz de Queiroz".

Empresa Brasileira de Pesquisa Agropecuária (2019). Sistema brasileiro de classificação de solos. Brasília, DF: EMBRAPA.

Ferreira, G. W., Roque, J. V., Soares, E. M., Silva, I. R., Silva, E. F., Vasconcelos, A.D. A., \& Teófilo,
R. F. (2018). Temporal decomposition sampling and chemical characterization of eucalyptus harvest residues using NIR spectroscopy and chemometric methods. Talanta, 188(1), 168-177. doi: 10.1016/j. talanta.20 18.05.073

Freitas, L., Oliveira, I. A., Silva, L. S., Frare, J. C. V., Filla, V. A., \& Gomes, R. P. (2017). Indicadores da qualidade química e física do solo sob diferentes sistemas de manejo. Revista Unimar Ciências, 26(1-2), 8-25.

Galindo, F. S., Montanari, R., Martins, M. M., Meirelles, F. C., Ludkiewicz, M. G., Silva, Y. D., \& Modenese, V. D. S. (2018). Specific management areas as a function of dendrometric properties of eucalyptus and physical-chemical attributes in an oxisol. Journal of Agricultural Science, 10(25), 34-51. doi: 10.5539/jas.v10n5p34

Kiehl, E. J. (1979). Manual de edafologia. São Paulo: Agronômica Ceres.

Klinke, G., Neto, Oliveira, A. H., \& Pereira, S. Y. (2017). Variabilidade espacial de atributos físicos do solo em uma sub-bacia às Margens do rio Mogi Guaçu (SP). São Paulo, UNESP. Geociências, 36(2), 381-394. doi: 10.5016/geociencias.v36i2.12593

Lavelle, P., Blanchart, E., Martin, S., Martin, A., Barois, S., Toutain, F., Schaefer, R. (1993). A hierarchical model for decomposition in terrestrial ecosystem. Application to soils in the humid tropics. Biotropica, 25(2), 130-150. doi: $10.2307 / 2389178$

Lima, C. G. R., Carvalho, M. P., Narimatsu, K. C. P., Silva, M. G., \& Queiroz, H. A. (2010). Atributos físico-químicos de um latossolo do Savannah brasileiro e sua relação com características dendrométricas do eucalipto. Revista Brasileira de Ciência do Solo, 34(1), 163-173. doi: 10.1590/S010006832010000100017 
Lima, E. S., Montanari, R., Lovera, L. H., Teixeira, M. C. M., Fo., \& González, A. P. (2017). Variabilidade espacial das propriedades dendrométricas do eucalipto e atributos químicos de um Neossolo Quartzarênico. Revista de Agricultura Neotropical, 4(1), 1-11. doi: 10.32404/rean.v4i1.1194

Machado, L. O., Lana, A. M. Q., Lana, R. M. Q., Guimarães, E. C., \& Ferreira, C. V. (2007). Variabilidade espacial de atributos químicos do solo em áreas sob sistema plantio convencional. Revista Brasileira de Ciência do Solo, 31(3), 591-599. doi: 10.1590/S0100-06832007000300019

Montanari, R. (2009). Aspectos daprodutividade do feijoeiro correlacionados com atributos do solo sob sistemas de manejo de elevado nível tecnológico. Tese de doutorado em Sistemas de Produção, Faculdade de Engenharia de Ilha Solteira, Universidade Estadual Paulista, Ilha Solteira, SP, Brasil.

Moraes, M. T. de, Debiasi, H., Franchini, J. C., Mastroberti, A. A., Levien, R., Leitner, D., \& Schnepf, A. (2020). Soil compaction impacts soybean root growth in an Oxisol from subtropical Brazil. Soil and Tillage Research, 200(1), 104611. doi: 10.1016/j. still.2020.104611

Neves, D. N., Santos., Neto, A. C., Santos, P. M., Melo, J. C., \& Santos, J. S. (2013). Análise espacial de atributos do solo e cobertura vegetal em diferentes condições de pastagem. Revista Brasileira de Engenharia Agrícola e Ambiental, 17(9), 995-1004. doi: 10.1590/S1415-43662013000900013

Novak, E., Carvalho, L. A., Santiago, E. F., Brumatti, A. V., Santos, L. L., \& Sales, L. C. (2018). Variação temporal dos atributos microbiológicos do solo sob diferentes usos. Revista de Ciências Agrárias, 41(3), 603-611. doi: 10.19084/RCA17300
Pimentel-Gomes, F., \& Garcia, C. H. 2002. Estatística aplicada a experimentos agronômicos e florestais: exposição com exemplos e orientações para uso de aplicativos. Piracicaba: Fealq.

Pizzani, R., Schaefer, P. E., Deloss, J., Pelizzon, M., \& Aleluia, D. A. (2018). Atividade microbiana e indicadores microbiológicos em latossolo vermelho sob diferentes sistemas de manejo. Enciclopédia Biosfera, 15(28) 139-150. doi: 10.18677/ EnciBio 2018B13

Robertson, G. P. (2008). GS+: Geostatistics for the Environmental Sciences. Gamma Design Software, Plainwell.

Santos, A. C. A., Silva, A., Leite, H. G., \& Cruz, J. P. (2017). Influência da variabilidade edafoclimática no crescimento de clones de eucalipto no Nordeste baiano. Pesquisa Florestal Brasileira, 37(91), 259-268. doi: 10.4336/2017.pfb.37.91.1207

Santos, T.E.B.,Melo,M.A.,Ramos, T.V.,Souza,A.G. V., \& Brandao, T. P. (2018). Comportamento da comunidade microbiana no sistema silviagrícola na região de savannah. Revista Agrotecnologia, 9(2), 18-27. doi: 10.12971/2179-5959/agrotecnologia.v9 $\mathrm{n} 2 \mathrm{p} 18-27$

Schlotzhaver, S. D., \& Littell, R. C. (1997). SAS system for elementary statical analysis (2nd ed.). Cary: SAS.

Schumacher, M. V., \& Viera, M. (2016). Silvicultura do eucalipto no Brasil. Santa Maria, UFSM.

Shanmugam, R., \& Chattamvelli, R. (2016). Skewness and kurtosis.

Shapiro, S. S., \& Wilk, M. B. (1965). An analysys of vari-ance test for normality: complete samples. Biometrika, 52(3/4), 591-611. doi: $10.2307 / 2333709$ 
Silva, A. O., Silva, W. M., Mercante, F. M. (2012). Método alternativo para quantificação do carbono da biomassa microbiana do solo. In Seminário de agroecologia de Mato Grosso do Sul, 4.; encontro de produtores agroecológicos de MS, 3., 2012, Glória de Dourados. Osaber tradicionale o científico: a interação encurtando caminhos para o desenvolvimento sustentável: anais. Brasília, DF: Embrapa, 2012.

Silva, J. C. da, Olszevski, N., Pereira, J. S., \& Silva, E. P. da. (2020). Influence of soil compaction levels on cowpea production. Reveng, 28(1), 1-10. doi: 10.13083/reveng. v28i.920

Silva, S. M. A., Lacotelli, M., Nunes, A. C. S., Oliveira, C. P., Sampaio, F. A. R., Mandu, T. S., \& Silva, C. A. (2021). Resistência mecânica do solo à penetração associado à umidade, densidade, Granulometria e Macronutrientes em Ji-Paraná-RO. Brazilian Journal of Development, 7(1), 5629-5647. doi: 10.34117/bjdv7n1-383

Stefanoski, D. C., Santos, G. G., Marchão R. L., Petter, F. A., \& Pacheco, L. P. (2013). Uso e manejo do solo e seus impactos sobre a qualidade física. Revista Brasileira de Engenharia Agrícola e Ambiental, 17(12), 1301-1309. doi: 10.1590/S141543662013001200008

Stolf, R., Murakami, J. H., Brugnaro, C., Silva, L. G., Silva, L. C. F., \& Margarido, L. A. C. (2014). Penetrômetro de impacto Stolf programa computacional de dados em EXCEL-VBA. Revista Brasileira de Ciência do Solo, 38(3), 774-782. doi: 10.1590/ S0100-06832014000300009
Tanvir, M. A., Siddiqui, M. T., \& Shah, A. H. (2002). Growth and price trend of Eucalyptus camaldulensis in central Punjab. International Journal of Agriculture \& Biology, 4(3), 344-346.

Teixeira, P. C., Donagemma, G. K., Fontana, A., \& Teixeira, W. G. (2017). Manual de métodos de análise de solos (3a ed. revisada e ampliada). Brasília: EMBRAPA Solos. Vieira, S. R. (2000). Geoestatística em estudos de variabilidade especial do solo. In R. F. Novais, V. H. Alvarez, \& C. E. G. R. Schaefer (Eds.), Tópicos em ciência do solo (vol. 1, pp. 1-53). Viçosa, MG: SBCS.

Vinhal-Freitas, I. C., Corrêa, G. F., Wendling, B., Bobuská, L., \& Ferreira, A. S. (2017). Soil textural class plays a major role in evaluating the effects of land use on soil quality indicators. Ecological Indicators, 1(74), 182-190. doi: 10.1016/j. ecolind.2016.11.020

Wardle, D. A. (1992). A comparative assessment of factors which influence microbial biomass carbon and nitrogen levels in soil. Biological Reviews, 67(1), 321-358, 1992. doi: 10.1111/j.1469-185X.1992.tb00728.x

Wardle, D. A. (1998). Controls of temporal variability of the soil microbial biomass: a global-scale synthesis. Soil Biolofical Biochemitry, 13(1), 1627-1637. doi: 10.10 16/S0038-0717(97)00201-0 
